\title{
Relationship of antibody affinity to onset of immune complex disease in New Zealand mice
}

\author{
R. E. PETTY AND M. W. STEWARD \\ From the Sections of Pediatric Rheumatology and Immunology, Department of Pediatrics and Communicable \\ Diseases, University of Michigan, Ann Arbor, and Laboratory of Immunochemistry, Division of Immunology, \\ Kennedy Institute of Rheumatology, London
}

SUMMARY Affinity $\left(K_{R}\right)$ of antibody to human serum transferrin in New Zealand mice was measured by a globulin precipitation technique. $K_{R}$ was low in mice immunized early in life, increased with age of immunization up to 16-26 weeks, and then fell to low levels. $K_{R}$ in young and old NZB mice was increased by immunization with antigen in Freund's complete adjuvant. The correlation between low affinity antibody production and susceptibility to immune complex disease is discussed.

The New Zealand Black (NZB) mouse, New Zealand White (NZW) mouse, and the first generation offspring $\left(\mathrm{NZW} / \mathrm{W} \mathrm{F}_{1}\right)$ of the cross between NZB and NZW mice have been extensively studied because of their susceptibility to a disease similar to systemic lupus erythematosus (Helyer and Howie, 1963; Mellors, 1966; Howie and Helyer, 1968; East, 1970). The demonstration of immunoglobulin and complement components in the renal glomeruli (Aarons, 1964; Mellors, 1965; Lambert and Dixon, 1968) and the presence of circulating antibody to nuclear constituents and to other antigens (Howie and Helyer, 1968; McGiven and Ghose, 1968; Siegel et al., 1972) suggest that the glomerulonephritis of the NZ mice, like that of systemic lupus erythematosus in man, is mediated by immune complexes. Immune complex nephritis can be induced in some strains of mice by neonatal infection with lymphocytic choriomeningitis (LCM) virus. Oldstone and Dixon (1969) have shown that while some strains (B1OD2 new and SWR) are susceptible to such nephritis, others $(\mathrm{C} 3 \mathrm{H}$ and $\mathrm{A} / \mathrm{jax})$ are resistant. In previous studies (Soothill and Steward, 1971 ; Petty et al., 1972), we showed that in addition to quantitative differences in antibody produced by these two groups of mice, there are demonstrable qualitative differences; that is, there are differences in the relative affinity $\left(\mathrm{K}_{\mathrm{R}}\right)$ of the antibody produced to protein and hapten antigens. Thus, those strains which are resistant to LCM-induced nephritis made

Accepted for publication May 17, 1976

Correspondence to Dr. M. W. Steward, Division of Immunology, Kennedy Institute of Rheumatology, Bute Gardens, London W67DW antibody of higher affinity to human serum albumin, human serum transferrin (HST), bovine serum albumin, dinitrophenol-human serum albumin, and nitrophenylacetic acid-rabbit serum albumin than did those strains which were susceptible to the LCM-induced disease.

Because of the possible relevance of antibody affinity to immune complex disease in NZ mice, previous studies (Petty and Steward, 1972) were conducted in these mice using HST as the antigen. Three observations were made. First, the relative affinity of anti-HST antibody in NZB and NZB/W $F_{1}$ mice immunized at 8-12 weeks of age was lower than that seen in any of the 12 other strains tested. Second, the $K_{R}$ rose with age at immunization through the age range tested (up to 26 weeks). This was a unique observation since none of the other strains previously tested showed this age-related variation. Third, immunization with antigen in Freund's complete adjuvant (FCA) in young mice significantly increased both levels and affinity of antibody.

This study is a continuation of earlier studies and examines the relative affinity of antibody produced to HST injected in saline into NZ mice at 26-52 weeks of age, and the ability of old NZ mice to produce high affinity antibody in response to immunization with antigen in FCA.

\section{Methods}

Mice were raised by brother-sister mating in a colony originally kept at the Institute of Child Health and subsequently at the Kennedy Institute. 
Hybrid $\left(\mathrm{NZB} / \mathrm{W} \mathrm{F}_{1}\right)$ mice were raised by reciprocal crosses between NZB and NZW mice. Groups of 8 male and female NZB, NZW, and NZB/W $F_{1}$ mice were immunized by intraperitoneal injection of $0.5 \mathrm{mg}$ HST (Sigma Chemical) at weekly intervals for 4 weeks and blood was obtained by cardiac puncture 2 weeks after the last injection.

Groups of 7- to 12-week-old NZB males and 48- to 52-week-old NZB males were also immunized intraperitoneally with $0.5 \mathrm{mg}$ HST in FCA (Difco, Detroit; 1:1 FCA:saline emulsion) at weekly intervals for 4 weeks and bled 2 weeks after the last injection. Determination of antibody affinity $\left(K_{R}\right)$ and amount $\left(\mathrm{Ab}_{\mathrm{t}} \mathrm{pmol} / 10 \mu \mathrm{l}\right)$ was performed as previously described using an ammonium sulphate globulin precipitation method (Steward and Petty, 1972a, b). Negative and positive control sera were included with each assay. Nonspecific binding (seen in the negative control) was subtracted from the test values.

\section{Results}

\section{NZB MICE}

The mean values for $K_{R}$ and $A b_{t}$ of anti-HST antibody in NZB mice immunized at various ages are shown in Table 1, and the individual values for $K_{R}$ are shown in Fig. 1. The rise in $K_{R}$ with increasing age of immunization up to 26 weeks previously reported (Petty and Steward, 1972) was confirmed with larger groups of mice. The mean $K_{R}$ was highest in NZB adult males immunized at 16 weeks, but fell thereafter. The $K_{R}$ of antibody from mice immunized at 52 weeks of age (mean $K_{R}=1.37 \times 10^{5}$ ) was not significantly different from that produced by mice immunized at 8-12 weeks of age (mean $K_{R}=$ $2.09 \times 10^{5}$ ). A similar pattern was seen with NZB females. In NZB females immunized at 26 weeks of age, mean $\mathrm{K}_{\mathrm{R}}=5.5 \times 10^{5} \mathrm{l} / \mathrm{mol}$ but fell to a low of $1.37 \times 10^{5} \mathrm{l} / \mathrm{mol}$ in those immunized at 52 weeks,

Table 1 Antibody response in NZB mice

\begin{tabular}{|c|c|c|c|c|}
\hline $\begin{array}{l}\text { Age at } \\
\text { immunization } \\
\text { (w) }\end{array}$ & $\begin{array}{l}\text { No. } \\
\text { immunized }\end{array}$ & $\begin{array}{l}\text { No. } \\
\text { responding }\end{array}$ & $\begin{array}{l}A b_{\mathrm{t}}(\mathrm{pmol} / \\
10 \mu l \text { serum }) \\
\text { (mean) }\end{array}$ & $\begin{array}{l}K_{\mathrm{R}}(\mathrm{l} / \mathrm{mol} \times \\
\left.10^{5}\right) \\
(\text { mean })\end{array}$ \\
\hline $\begin{array}{r}\text { Male } \\
8-12 \\
16 \\
26 \\
40 \\
52\end{array}$ & $\begin{array}{r}14 \\
5 \\
13 \\
10 \\
7\end{array}$ & $\begin{array}{r}7 \\
5 \\
11 \\
10 \\
7\end{array}$ & $\begin{array}{r}11 \cdot 4 \\
12.4 \\
9 \cdot 0 \\
14 \cdot 3 \\
18.9\end{array}$ & $\begin{array}{l}2 \cdot 09 \\
8 \cdot 26 \\
6 \cdot 52 \\
3 \cdot 76 \\
1 \cdot 37\end{array}$ \\
\hline $\begin{array}{c}\text { Female } \\
8-12 \\
16 \\
26 \\
40 \\
52\end{array}$ & $\begin{array}{r}21 \\
8 \\
9 \\
6 \\
8\end{array}$ & $\begin{array}{r}14 \\
7 \\
9 \\
6 \\
7\end{array}$ & $\begin{array}{c}11 \cdot 2 \\
7 \cdot 6 \\
10 \cdot 2 \\
6 \cdot 6 \\
10 \cdot 16\end{array}$ & $\begin{array}{l}2 \cdot 5 \\
3 \cdot 10 \\
5 \cdot 52 \\
1 \cdot 88 \\
1 \cdot 37\end{array}$ \\
\hline
\end{tabular}

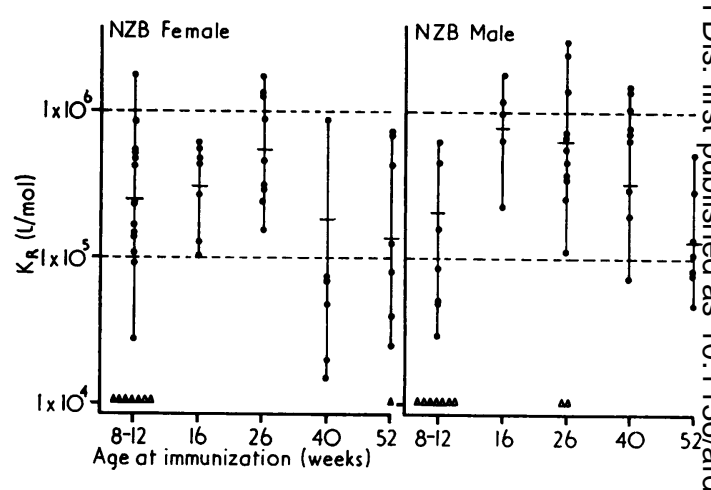

Fig. $1 K_{\mathrm{R}}$ of anti-HST antibody in NZB mice immunized at $8-52$ weeks of age. Each $\bullet$ represents a single mouse. $\Delta \Delta$ represent mice with no detectable antibody.

a slightly lower value than that obtained in mic $\overrightarrow{1}$ immunized at 8-12 weeks (mean $K_{R}=2.5 \times 1 \%$ $1 / \mathrm{mol}$ ). In both groups the incidence of nonrespon ders (that is, those mice making no detectable ant body) was greater in the younger mice than in olden mice. Although $A b_{t}$ did show some variations particularly in females, there was no clear association between $K_{R}$ and $A b_{t}$.

\section{NZW MICE}

In the NZW mice, although the $K_{R}$ was low, the high proportion of nonresponders at young and very old ages made assessment difficult. In NZW males the mean $K_{R}$ was lower than that in NZW females but there was no demonstrable age dependence (Table 2).

Table 2 Antibody response in $N Z W$ mice

\begin{tabular}{|c|c|c|c|c|}
\hline $\begin{array}{l}\text { Age at } \\
\text { immunization } \\
(w)\end{array}$ & $\begin{array}{l}\text { No. } \\
\text { immunized }\end{array}$ & $\begin{array}{l}\text { No. } \\
\text { responding }\end{array}$ & $\begin{array}{l}A b_{\mathrm{l}}(\mathrm{pmol} / \\
10 \mu / \text { serum }) \\
\text { (mean) }\end{array}$ & $\begin{array}{l}K_{\mathrm{R}} l / m o l \times \\
\left.10^{5}\right) \\
(\text { mean })\end{array}$ \\
\hline \multicolumn{5}{|l|}{ Male } \\
\hline 8 & 12 & 4 & 8.0 & $2 \cdot 13$ \\
\hline 26 & 9 & 9 & 4.2 & $2 \cdot 17$ \\
\hline & 9 & 1 & $(11 \cdot 0)$ & $(1 \cdot 40)$ \\
\hline \multicolumn{5}{|l|}{ Female } \\
\hline 8 & 12 & 6 & $3 \cdot 50$ & $4 \cdot 82$ \\
\hline 26 & 4 & 1 & $(7 \cdot 0)$ & $(3 \cdot 6)$ \\
\hline 40 & 5 & 5 & $6 \cdot 86$ & 4.7 \\
\hline
\end{tabular}

In the $\mathrm{NZB} / \mathrm{W} \mathrm{F}$ males there was an age-dependeft decline in $K_{R}$ similar to that in the NZB males (Table 3, Fig. 2). After reaching a maximal mean $K_{R}$ of $8.96 \times 10^{5}$ in mice immunized at 26 weeks of age, the values in mice immunized at a later age progressively declined to a mean of $0.93 \times 10^{5}$ for those immunized at 52 weeks of age. The rarity 8 
females of this type surviving until 40 to 52 weeks of age prevented their study. Unlike the NZB mice, the $\mathrm{B} / \mathrm{W} \mathrm{F}_{1}$ mice tended to make higher levels of antibody with increasing age at immunization.

Table 3 Antibody response in $N Z B / W F_{1}$ mice

\begin{tabular}{|c|c|c|c|c|}
\hline $\begin{array}{l}\text { Age at } \\
\text { immunization } \\
(w)\end{array}$ & $\begin{array}{l}\text { No. } \\
\text { immunized }\end{array}$ & $\begin{array}{l}\text { No. } \\
\text { responding }\end{array}$ & $\begin{array}{l}\text { Ab } b_{\mathrm{t}}(\text { pmoll } \\
10 \mu \text { l serum }) \\
(\text { mean })\end{array}$ & $\begin{array}{l}K_{\mathrm{R}}(l / \mathrm{mol} \times \\
\left.10^{5}\right) \\
(\mathrm{mean})\end{array}$ \\
\hline \multicolumn{5}{|l|}{ Male } \\
\hline $8-12$ & 28 & 11 & 13.4 & $3 \cdot 15$ \\
\hline 26 & 13 & 13 & 15.9 & 8.96 \\
\hline 40 & 5 & 5 & 18.0 & 1.83 \\
\hline 52 & 7 & 7 & 40.0 & 0.93 \\
\hline \multicolumn{5}{|l|}{ Female } \\
\hline $8-12$ & 25 & 18 & 14.0 & 1.50 \\
\hline 16 & 9 & 7 & 6.0 & 2.90 \\
\hline 26 & 14 & 7 & $18 \cdot 5$ & 5.66 \\
\hline
\end{tabular}

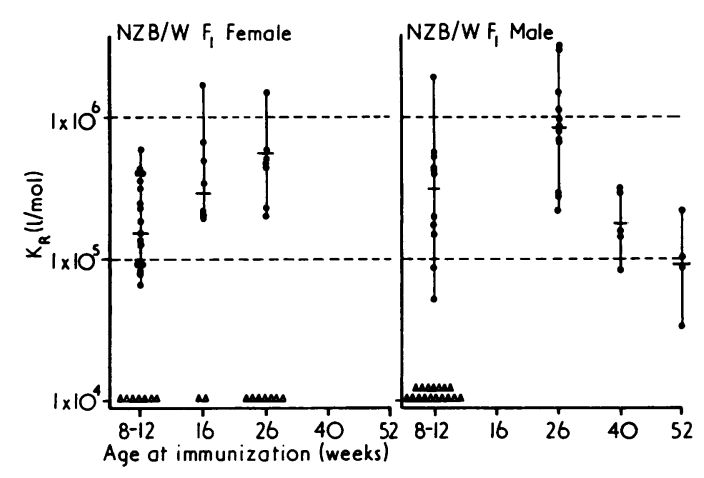

Fig. $2 K_{\mathrm{R}}$ of anti-HST antibody in $N Z B / W F_{1}$ mice immunized at 8-52 weeks of age. Each $\bullet$ represents a single mouse. $\Delta \Delta$ represent mice with no detectable antibody.

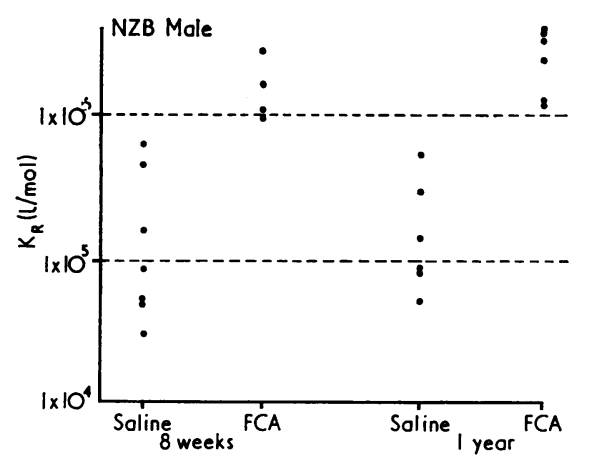

Fig. 3 Effect of Freund's complete adjuvant (FCA) on $K_{\mathrm{R}}$ of anti-HST antibody in young and old NZB male mice. Each $\bullet$ represents a single mouse.
EFFECT OF FCA ON $K_{R}$ IN OLD NZB MICE

As the data in Table 1 indicate, the $K_{R}$ of antibody in old NZB mice was very low when antigen was administered in saline. When antigen was administered in FCA, however, the $\mathrm{K}_{\mathbf{R}}$ of antibody in old mice was even higher than that made in the young mice similarly immunized (Fig. 3). Mean $A b_{t}$ of 8 to 12 -week-old male NZB mice immunized with antigen in saline was $12.5 \mathrm{pmol} / 10 \mu \mathrm{l}$ and in FCA $34 \mathrm{pmol} / 10 \mu \mathrm{l}$. For 52-week-old NZB males the mean $\mathrm{Ab}_{\mathrm{t}}$ of those immunized with antigen in saline was $18.9 \mathrm{pmol}$, and in FCA $180 \mathrm{pmol} / 10 \mu \mathrm{l}$. Thus, the effect of adjuvant on $\mathrm{Ab}_{\mathrm{t}}$ appeared to be much greater in the old mice than in the young mice, although both responded about equally with respect to $\mathbf{K}_{\mathbf{R}}$.

\section{Discussion}

The previously reported increase in $K_{R}$ of antibody to HST with increasing age in NZ mice is followed by a decline in mice immunized beyond 16-26 weeks of age. This is accompanied by small changes in $\mathrm{Ab}_{\mathrm{t}}$. Extensive studies (Mellors, 1966; Howie and Helyer, 1968; Lambert and Dixon, 1968; East, 1970) have shown the age-dependence of many of the autoimmune phenomena, proteinuria, and renal glomerular histopathological changes in NZ mice. Recently a similar age-dependent variation in avidity of antibody to native DNA was shown in these mice (Steward et al., 1975), with maximum avidity occurring at 20 weeks in both male and female NZB/W $F_{1}$ mice. As with $K_{R}$ of antibody to HST, the avidity of antibody to DNA falls with age. The striking sex differences in avidity of anti-DNA antibody to NZB/W $F_{1}$ mice, males being higher than females, was not seen with anti-HST antibody. Other studies (Elkerbout and Hijmans, 1974a, b) give indirect evidence for production of low affinity antibodies in old NZB mice.

In the case of antibodies to DNA, the $\mathrm{K}_{\mathrm{R}}$ of antiDNA present in the serum of older animals may be different from the $K_{R}$ of anti-DNA antibody deposited as immune complex in the renal glomeruli. Thus the reported fall in serum anti-DNA $K_{R}$ could reflect selective deposition of high $K_{R}$ antiDNA antibody in glomeruli. The fall in $K_{R}$ of serum anti-HST could reflect the same phenomenon although HST or other heterologous proteins are not known to participate in the NZ mouse immune complex nephritis. While this explanation cannot at present be refuted, the alternative explanation is that the mean $\mathrm{K}_{\mathrm{R}}$ of anti-HST antibody synthesized varies with age at immunization.

The mechanisms which determine $K_{R}$ are not known, although it is apparent from the work of 
Andersson (1972) and others that the affinity of circulating antibody is representative of the affinity of the B-cell surface immunoglobulins. The responsiveness of old NZ mice to immunization with antigen in adjuvant suggests that the low $\mathbf{K}_{\mathbf{R}}$ antibody elic ited by antigen in saline is not an absolute defect in B-cells. It is important to consider whether agedependent alterations in T-cells or macrophages could result in the observed age-dependent alterations in $K_{R}$. Reports have noted the decline in $T$ lymphocyte responses with increasing age in NZ mice (Talal, 1970; Rodey et al., 1971; Bach et al., 1973) and the efficacy of thymosin in correcting this abnormality (Dauphinee et al., 1974; Gershwin et al., 1974). Although deficient T-cell function might explain failure of T-B cell co-operation and resultant low affinity antibody in the old mouse, it could not, on the basis of present data, explain the low $K_{R}$ values seen in the very young mouse.

Less attention has been paid to the function of macrophages in NZ mice. Thomas and Weir (1972) showed that peritoneal exudate cells of old NZB mice take up more bovine serum albumin than do such cells from young mice but that old NZB mice failed to degrade such protein as efficiently as the younger mice. Using the clearance of ${ }^{125}$. labelled polyvinylpyrrolidone as a measure of macrophage function, it had been shown that macrophage function in $\mathrm{NZB} / \mathrm{W} \mathrm{F}_{1}$ mice declines with increasing age (Morgan and Steward, 1976). Such reticuloendothelial inefficiencies could contribute to less efficient processing of antigen and thus to lower antibody affinity.

If, as we have postulated, antibody of low affinity is important in determining predisposition of an animal to chronic soluble complex disease, it might be expected that production of low affinity antibody would occur either at the time at which immunization with the immunopathogenic antigen takes place, or at the time of onset of immune complex disease. The demonstration within the first week of life of antibody to DNA in NZ mice (Siegel et al., 1972) suggested that transplacental or nennatal infection with virus could be the initial eve'nt leading to immune complex disease. The data of Steward et al. (1975) with respect to anti-DNA and the data presented here with respect to HST support the suggestion that both at the time of initial (neonatal) immunization and at the time of occurrence of severe disease (after 6 months of age) the mean $K_{R}$ of serum antibody is low.

It is clear that demonstration of low affinity antibody to HST does not prove the production of or the pathogenic potential of low affinity antibody to viral agents. An assumption must be made that, within limits, NZ mice make low affinity antibody to many, if not all antigens, and that the relatively loow affinity of anti-HST antibody accurately reflects the potential of that strain for making antibody of an given affinity. Studies of other strains have shovg that 'high affinity strains' (A, C3H) make antibody of high affinity to all antigens tested (HST, DNA human and bovine serum albumin, dinitropheno human serum albumin, nitrophenylacetic aciog, whereas 'low affinity strains' make antibody of low affinity to the same antigens. Therefore, the affinily of the antibody response may be central to the disease process. The demonstrated effect of adjuvant substances on such a response may be of potentiogll therapeutic importance in preventing or treatiang such disease.

The age-dependent variations in affinity of anti body to HST and to DNA (Steward et al., 1975) afe difficult to ascribe to a single mechanism. It is likefy that such variations arise as a result of the interaction of the several age-related deficiencies alrea $\phi y$ clearly described for these mice.

This work was initiated at the Institute of Child Health, University of London, while one of $\vec{s}$ (R.E.P.) was the recipient of a Canadian Arthritis and Rheumatism Society fellowship. Subsequent support was provided in part by Medical Researêt Council Grant G 972/792 to M.W.S.

\section{References}

Aarons, I. (1964). Renal immunofluorescence in NZB/NZ mice. Nature, 203, 1080-1081.

Andersson, B. (1972). Studies on antibody affinity at the cellular level. Journal of Experimental Medicine, 135, 31 2 322.

Bach, J.-F., Dardenne, M., and Salmon, J.-C. (197). Studies of thymus products. IV. Absence of serum thynac activity in adult NZB and $(\mathrm{NZB} \times \mathrm{NZW}) \mathrm{F}_{1}$ mice. Clinicel and Experimental Immunology, 14, 247-256.

Dauphinee, M. J., Talal, N., Goldstein, A. L., and White, (1974). Thymosin corrects the abnormal DNA synthef response of NZB mouse thymocytes. Proceedings of the National Academy of Sciences of the U.S.A., 71, 2637-2641.

East, J. (1970). Immunopathology and neoplasms in New Zealand Black (NZB) and SJL/J mice. Progress in Expesmental Tumor Research, 13, 84-91.

Elkerbout, E. A. S., and Hijmans, W. (1974a). The longterm antibody response of New Zealand Black mice 90 sheep red blood cells. Immunology, 26, 893-900.

Elkerbout, E. A. S., and Hijmans, W. (1974b). Relat avidity of antibodies toward sheep red blood cells in New Zealand Black mice. Immunology, 26, 901-907.

Gershwin, M. E., Ahmed, A., Steinberg, A. D., Thurmą, G. B., and Goldstein, A. L. (1974). Correction of T oell function by thymosin in New Zealand Mice. Journal $\mathscr{B}_{f} f$ Immunology, 113, 1068-1071.

Helyer, B. J., and Howie, J. B. (1963). Renal disease assoçated with positive lupus erythematosus tests in a cross-bied strain of mice. Nature, 197, 197.

Howie, J. B., and Helyer, B. J. (1968). The immunolo and pathology of NZB mice. Advances in Immunology, 2 , 215-266. 
Lambert, P. H., and Dixon, F. J. (1968). Pathogenesis of the glomerulonephritis of NZB/W mice. Journal of Experimental Medicine, 127, 507-521.

McGiven, A. R., and Ghose, T. (1968). Antinuclear factor in NZB/NZW mice: incidence and in vitro effects. Clinical and Experimental Immunology, 3, 657-663.

Mellors, R. C. (1965). Autoimmune disease in NZB/B1 mice. I. Pathology and pathogenesis of a model system of spontaneous glomerulonephritis. Journal of Experimental Medicine, 122, 25-31.

Mellors, R. C. (1966). Autoimmune and immunoproliferative diseases of NZB/B1 mice and hybrids. International Review of Experimental Pathology, 5, 217-231.

Morgan, A. G., and Steward, M. W. (1976). Macrophage clearance function and immune complex disease in New Zealand Black/White F, hybrid mice. Clinical and Experimental Immunology, 26, 133-136.

Oldstone, M. B. A., and Dixon, F. J. (1969). Pathogenesis of chronic disease associated with persistent lymphocytic choriomeningitis viral infection 1. Journal of Experimental Medicine, 129, 483-499.

Petty, R. E., and Steward, M. W. (1972). Relative affinity of antiprotein antibodies in New Zealand mice. Clinical and Experimental Immunology, 12, 343-350.

Petty, R. E., Steward, M. W., and Soothill, J. F. (1972). The heterogeneity of antibody affinity in inbred mice and its possible immunopathologic significance. Clinical and Experimental Immunology, 12, 231-241.
Rodey, G. E., Good, R. A., and Yunis, E. J. (1971). Progressive loss in vitro of cellular immunity with ageing in strains of mice susceptible to autoimmune disease. Clinical and Experimental Immunology, 9, 305-311.

Siegel, B. V., Brown, M., and Morton, J. I. (1972). Detection of antinuclear antibodies in NZB and other mouse strains. Immunology 22, 457-463.

Soothill, J. F., and Steward, M. W. (1971). The immunopathological significance of the heterogeneity of antibody affinity. Clinical and Experimental Immunology, 9, 193-199.

Steward, M. W., and Petty, R. E. (1972a). The use of ammonium sulphate globulin precipitation for determination of affinity of anti-protein antibodies in mouse serum. Immunology, 22, 747-756.

Steward, M. W., and Petty, R. E. (1972b). The antigenbinding characteristics of antibody pools of different relative affinity. Immunology, 23, 881-887.

Steward, M. W., Katz, F. E., and West, N. J. (1975). The role of low affinity antibody in immune complex disease: the quantity of anti-DNA antibodies in NZB/W $F_{1}$ mice. Clinical and Experimental Immunology, 21, 121-130.

Talal, N. (1970). Immunologic and viral factors in the pathogenesis of systemic lupus erythematosus. Arthritis and Rheumatism, 13, 887-894.

Thomas, H. I. J., and Weir, D. M. (1972). The in vitro activity of peritoneal exudate cells from New Zealand Black mice (NZB/B1) in the presence of $1^{125}$-BSA (bovine serum albumin). Clinical and Experimental Immunology, 12, 263-272. 